\title{
Fermentation in broiler chicken gastrointestinal tract as affected by high dietary inclusion of barley and by $\beta$-glucanase supplementation
}

\author{
D. Józefiak ${ }^{1,2,5}$, S. Kaczmarek ${ }^{1}$, A. Rutkowski ${ }^{1}$, A. Józefiak ${ }^{3}$, \\ B.B. Jensen ${ }^{4}$ and R.M. Engberg ${ }^{4}$ \\ ${ }^{1}$ August Cieszkowski Agricultural University, \\ Department of Animal Nutrition and Feed Management \\ Wotyńska 33, 60-637 Poznań, Poland \\ ${ }^{3}$ University of Medical Sciences, \\ Department of Gynecological Oncology \\ Polna 33, 60-535 Poznań, Poland \\ ${ }^{4}$ Danish Institute of Agricultural Sciences, \\ Department of Animal Health, Welfare and Nutrition \\ P.O. Box 50, DK-8830 Tjele, Denmark
}

(Received 9 August 2005; revised version 23 September 2005; accepted 17 October 2005)

\begin{abstract}
Over a period of 5 weeks an experiment was performed with 192 one-day-old Cobb 500 cockerels, which were randomly divided into two experimental groups of 12 cages (replicates) of 8 birds each. The objective of the experiment was to estimate whether the supplementation of a barleybased diet with $\beta$-glucanase influences the performance and gastrointestinal ecosystems of broiler chickens in terms of ileal viscosity and $\mathrm{pH}$ as well as the concentration of short-chain fatty acids (SCFA) and lactic acid in different segments of the gastrointestinal tract.

In the period from day 15 to day 35 , dietary enzyme supplementation significantly improved FCR values (1.90 vs 1.85). Body weight gains, liver and caeca weights were not affected by $\beta$-glucanase inclusion. Enzyme supplementation decreased ileal viscosity $(\mathrm{P} \leq 0.05)$ and affected SCFA concentrations in the crop and caeca. In digesta from different gastrointestinal segments, lactic acid was detected at the highest levels in the ileum, followed by the crop, gizzard and caeca. The total concentration of SCFAs was found to be highest in the caeca, followed by the ileum, crop, and gizzard. In the crop, the concentrations of acetate, and in the caeca, those of propionate as well as of total SCFA, increased following dietary enzyme supplementation. In none of the examined gastrointestinal segments was the $\mathrm{pH}$ value affected $(\mathrm{P} \leq 0.05)$ by enzyme supplementation.
\end{abstract}

KEY WORDS: broiler chicken, barley, non-starch polysaccharides, $\beta$-glucanase, fermentation

\footnotetext{
${ }^{2}$ D. Józefiak is a recipient of support from The Foundation for Polish Science

${ }^{5}$ Corresponding author: e-mail: damjo@owl.au.poznan.pl
} 


\section{INTRODUCTION}

The carbohydrate fraction in barley contains soluble and insoluble (1-3)(1-4)$\beta$-glucans, a soluble fraction of non-starch polysaccharides (NSP), which may create a viscous environment within the intestinal lumen (Smith and Annison, 1996) and limit the use of barley in broiler chicken diets. Apart from the soluble NSP fraction, barley contains relatively high amounts of cellulose and, as compared with wheat, lower levels of starch (Bach Knudsen, 1997). In many European countries where barley is a domestic cereal, $\beta$-glucanase supplementation to poultry diets is a common practice (Elwinger and Säterby, 1987; Brenes et al., 1993; Jamroz et al., 2001; Svihus and Gullord, 2002). Brenes et al. (1993) reported that $\beta$-glucanase inclusion in barley-based diets not only improved broiler performance but also reduced the weight of the digestive tract by $13 \%$, and improved the post slaughter carcass value. The improvement of performance has been suggested to be due to the lowered viscosity of the digesta. However, the mode of the NSP degrading enzyme action is not completely understood (Lázaro et al., 2003; Józefiak et al., 2004a).

The presence of viscous polysaccharides has been shown to increase the intestinal microbial activity associated with poor broiler growth performance (Choct et al., 1996; Langhout et al., 1999). Feed enzymes can reduce the bacterial activity in the ileum by reducing the amount of nutrients available for microbial fermentation (Silva and Smithard, 2002). The end products of microbial fermentation in the chicken intestine may contribute a certain amount of energy to the host bird (Jamroz et al., 2002), and may further play an important role in regulating the microflora populations (Ricke, 2003). The concentrations of short-chain fatty acids (SCFA) and lactic acid in the broiler gastrointestinal tract (GIT) depend on the cereal type and feed enzyme inclusion (Jamroz et al., 2002; Silva and Smithard, 2002; Józefiak et al., 2004b) and reflect to a certain extent the activity of the resident microflora (Engberg et al., 2002).

The aim of the present study was to investigate whether the addition of $\beta$-glucanase to a barley-based diet influences the performance and gastrointestinal ecosystems of broiler chickens in terms of ileal viscosity and $\mathrm{pH}$ as well as the concentration of short-chain fatty acids and lactic acid in different segments of GIT.

\section{MATERIAL AND METHODS}

A total of 192 male broiler chickens (Cobb 500) were used in the experiment. The study design consisted of two dietary treatments with 12 replicate wire-floor cages with 8 chickens in each cage $\left(16\right.$ birds per $\left.\mathrm{m}^{2}\right)$. Over the entire experimental 
period (d 1-35), the animals were offered barley-based diets (Table 1), which were fed ad libitum as a mash in the starter (d 1-14) and grower (d 15- 35) periods.

TABLE 1

Composition ( $\mathrm{g} \mathrm{kg}^{-1}$ dry matter) and nutritional value of diets in the starter and grower period and analysed chemical composition of the barley carbohydrate fraction

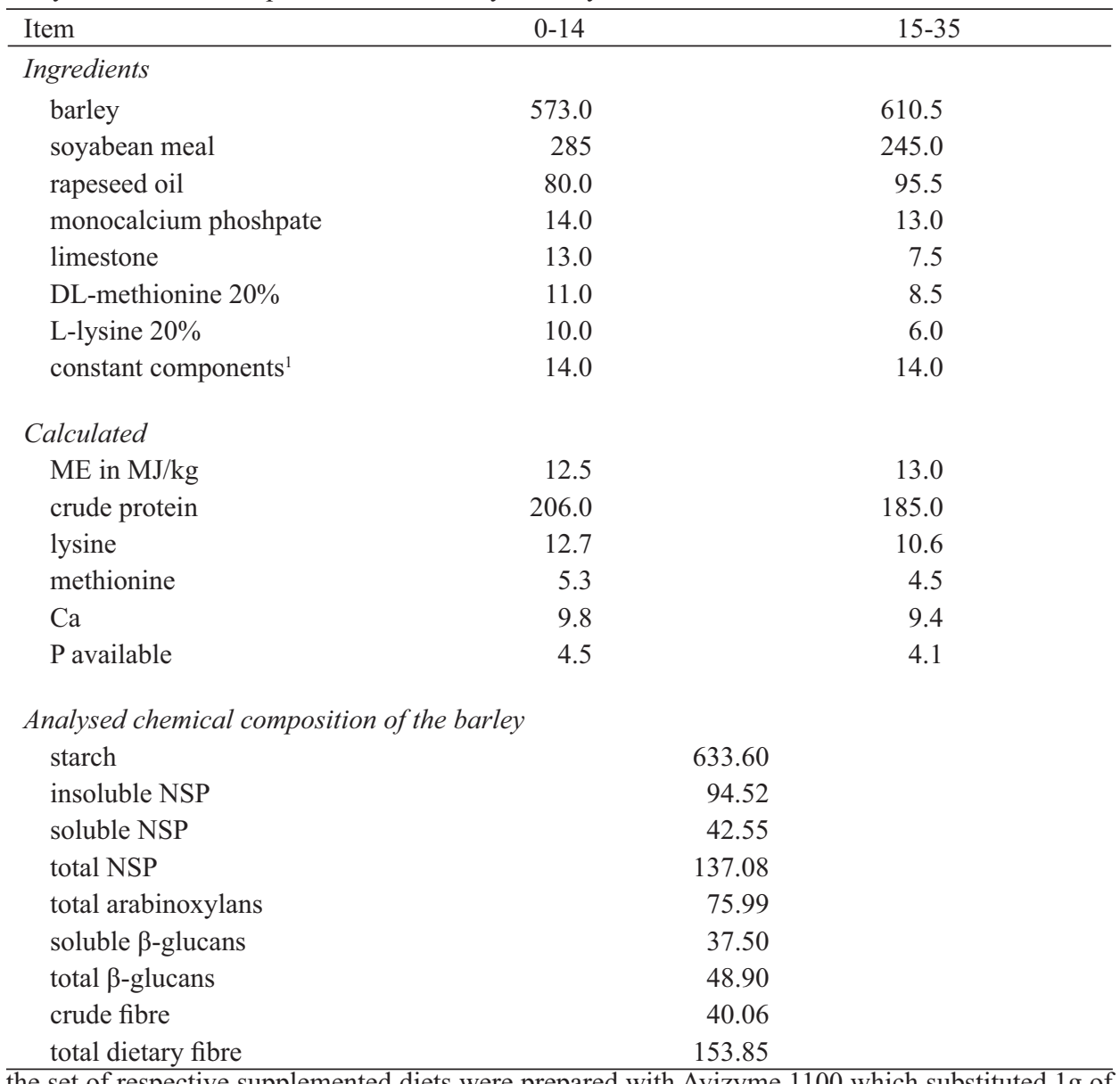

the set of respective supplemented diets were prepared with Avizyme 1100 which substituted 1g of cereal

${ }^{1}$ supplying per $\mathrm{kg}$ of diet: $\mathrm{NaCl} 3 \mathrm{~g}$; $\mathrm{NaHCO}_{3} 1 \mathrm{~g}$; and $10 \mathrm{~g}$ of mineral and vitamin premix

The barley was of Polish origin, Lot variety, harvested in the year 2003. Diets were prepared with or without the addition of $1 \mathrm{~g} / \mathrm{kg}$ feed Avizyme ${ }^{\circledR} 1100$ (Danisco, UK), containing in $1 \mathrm{~g}$ : $100 \mathrm{U}$ endo 1.3(4)- $\beta$-glucanase; $300 \mathrm{U}$ endo 1.4- $\beta$-xylanase and $800 \mathrm{U}$ protease, according to the producer's declaration. Soyabean meal was used as the protein source. Antibiotic growth promoters were not included in the diets, 
and salinomycine at $60 \mathrm{ppm}$ was used as an anticoccidial agent. Feed intake and body weights were registered at weekly intervals, and the feed conversion ratio (FCR) and body weight gain (BWG) were calculated. During two days in the fifth week of the experiment, 10 chickens from each group were sacrificed by cervical dislocation. The contents of the crop, gizzard, ileum (the small intestinal segment caudal to Meckel's diverticulum), and caeca were quantitatively collected for further analyses. After dissection, the liver was rinsed in sterile water and weighed. In order to determine the weight of the filled and empty intestinal segments, they were weighed with contents, rinsed in sterile water and weighed again.

The experiment complied with the guidelines of the Local Ethics Commission with respect to animal experimentation and care of animals under study.

\section{Analytical methods}

The dietary concentrations of dry matter, crude protein, crude fat, and starch were determined according to AOAC (1990). The non-starch polysaccharide fractions were analysed using the method described by Englyst and Cummings (1984).

Immediately following slaughter, the $\mathrm{pH}$-value of the contents in all gastrointestinal segments was measured with a combined glass/reference electrode (ElMetron CP 40, Poland). The viscosity of the ileal contents was estimated at a shear rate of $12 \mathrm{~s}^{-1}$ using a Brookfield Digital DV-II cone/plate viscometer (Brookfield Engineering Laboratories, Stoughton, USA) as described by Steenfeldt et al. (1998). The concentration of short-chain fatty acids and lactic acid in the contents of the different gastrointestinal segments was determined by gas chromatography as described by Jensen et al. (1995).

Statistical analysis of results was performed using the General Linear Models procedure (GLM) of the $\mathrm{SAS}^{\circledR}$ (SAS Institute, 1988).

\section{RESULTS}

The performance of broiler chickens is shown in Table 2. Supplementation of $\beta$-glucanase improved FCR values $(\mathrm{P} \leq 0.05)$ only in the grower period. Considering the entire experiment, enzyme supplementation exerted a positive effect on FCR but the differences (1.77 vs 1.81 ) were not statistically significant. Irrespective of the feeding period, no statistically significant effect of the enzyme addition on body weight gain was recorded. None of the experimental birds died during the experiment. Birds receiving barley-based diets with $\beta$-glucanase supplementation had a lower $(\mathrm{P} \leq 0.05)$ ileal chyme viscosity (Table 2$)$. Furthermore, the weight of the liver and caeca tended to be higher and the 
TABLE 2

Performance of the chickens, ileal digesta viscosity (mPas s), caeca and liver weight, $\mathrm{g} / \mathrm{kg}$ body weight

\begin{tabular}{lccc}
\hline \multirow{2}{*}{ Days } & \multicolumn{3}{c}{ Dietary treatment } \\
\cline { 2 - 4 } & barley & barley + enzyme & SEM \\
\hline FCR, $k g$ feed/kg BWG & 1.36 & 1.37 & 0.01 \\
$0-14$ & $1.90^{\mathrm{a}}$ & $1.85^{\mathrm{b}}$ & 0.01 \\
15-35 & 1.81 & 1.77 & 0.02 \\
$0-35$ & & & \\
Body weight gain, $g$ & 311 & 315 & 2.41 \\
$0-14$ & 1519 & 1553 & 11.3 \\
15-35 & 1868 & 1822 & 13.1 \\
$0-35$ & $3.77^{\mathrm{a}}$ & $2.19^{\mathrm{b}}$ & 0.31 \\
Ileal digesta viscosity viscosity & & & \\
Weight of caeca, $g$ & 19.35 & 23.18 & 1.24 \\
with digesta & 8.57 & 9.84 & 0.34 \\
emty caeca & 29.97 & 34.94 & 1.56 \\
Liver weight, $g$ & & & \\
\hline
\end{tabular}

caeca tended to contain greater amounts of digesta $(\mathrm{P}>0.05)$. In the digesta from different GIT segments, lactic acid was detected at the highest level in the ileum, followed by the crop, gizzard, and caeca (Table 3). The total concentration of SCFAs was found to be highest in the caeca, followed by the ileum, crop, and gizzard. Propionate was only detected in the caecal contents, whereas butyrate was also found in small amounts in the contents of the crop, gizzard, and ileum. Concentrations of SCFAs were affected by $\beta$-glucanase supplementation in the crop and caeca $(\mathrm{P} \leq 0.05)$. In the crop, the concentration of acetate and in the caeca, the concentration of propionate, as well as of total SCFAs, increased (Table 3).

TABLE 3

Concentration of the short chain fatty acids and lactic acid ( $\mu$ moles/g digesta), and $\mathrm{pH}$ of digesta in the crop, gizzard, ileum and caeca

\begin{tabular}{lccc}
\hline & \multicolumn{3}{c}{ Dietary treatment } \\
\cline { 2 - 4 } Crop & barley & barley + enzyme & SEM \\
acetate & & & \\
propionate & $4.20^{\mathrm{b}}$ & $6.43^{\mathrm{a}}$ & 0.57 \\
butyrate & $\mathrm{Nd}^{*}$ & $\mathrm{Nd}^{*}$ & - \\
lactic acid & 0.46 & $\mathrm{Nd}^{*}$ & 0.23 \\
total & 23.89 & 35.40 & 4.96 \\
$\mathrm{pH}$ & 28.56 & 41.84 & 5.12 \\
& 4.60 & 4.64 & 0.59 \\
\hline
\end{tabular}


TABLE 3 continued

\begin{tabular}{lccc}
\hline & \multicolumn{3}{c}{ Dietary treatment } \\
\cline { 2 - 4 } Gizzard & barley & barley + enzyme & SEM \\
acetate & & & \\
propionate & 5.00 & 4.81 & 0.71 \\
butyrate & $\mathrm{Nd}^{*}$ & $\mathrm{Nd}^{*}$ & - \\
lactic acid & 0.06 & $\mathrm{Nd}^{*}$ & 0.03 \\
total & 15.00 & 11.29 & 3.41 \\
pH & 20.06 & 16.10 & 4.08 \\
Ileum & 3.36 & 3.42 & 0.06 \\
acetate & & & \\
propionate & 13.73 & 13.28 & 1.35 \\
butyrate & $\mathrm{Nd}$ & $\mathrm{Nd}$ & - \\
lactic acid & $\mathrm{Nd}$ & 1.98 & 0.77 \\
total & 48.47 & 64.50 & 7.32 \\
pH & 62.20 & 79.7 & 8.40 \\
& 5.98 & 5.67 & 0.13 \\
Caeca & & & \\
acetate & & & \\
propionate & 71.86 & 75.09 & 2.55 \\
butyrate & $7.72^{\mathrm{b}}$ & $21.00^{\mathrm{a}}$ & 2.23 \\
lactic acid & 31.36 & 32.84 & 1.69 \\
total & 0.96 & 2.74 & 0.80 \\
pH & $111.92^{\mathrm{b}}$ & 6.21 & 4.62 \\
\hline
\end{tabular}

${ }^{a, b}$ means in the rows with different letters are significantly different at $\mathrm{P} \leq 0.05$

${ }^{*}$ not detected

In the contents of different GIT segments, no differences between experimental groups were found with respect to lactic acid concentration and $\mathrm{pH}(\mathrm{P} \geq 0.05)$.

\section{DISCUSSION}

In agreement with the results of other authors (Elwinger and Säterby, 1987; Brenes et al., 1993; Jamroz et al., 2001), the present study showed that the addition of $\beta$-glucanase to a barley-based diet improved the FCR in the grower period. However, considering the entire experiment, only a tendency $(2.2 \%)$ was observed. Reduction of intestinal chyme viscosity is suggested to be the main functions of exogenous enzymes that reduce the antinutritive nature of watersoluble NSP. Thus, many authors (Bergh et al., 1999; Silva and Smithard, 2002) explain the beneficial role of microbial enzyme preparations by their action in 
the ileum. In the present experiment, the viscosity of the ileal digesta was lower than observed in other experiments with broilers fed different barley varieties (Svihus and Gullord, 2002), but similar to earlier findings when other Polish varieties of barley were fed (Józefiak et al., 2004a). Lower viscosity after enzyme supplementation can partially explain better feed conversion, due to improved absorption and transport of nutrients (Smith and Annison, 1996). Bedford and Apajalahti (2001) suggested that the action of exogenous enzymes may be described to proceed in two phases, as the ileal phase and the caecal phase. During the ileal phase, enzymes prevent the formation of viscous digesta, whereas during the caecal phase, degradation products, such as xylose and xylo-oligomers, are fermented by caecal microbes, thus stimulating the production of short-chain fatty acids. In the present experiment, in all of the examined GIT segments (i.e. crop, gizzard, ileum, caeca) different SCFAs were detected. Similarly to findings of other authors (Jamroz et al., 2001; Engberg et al., 2002), among the GIT segments, the highest concentrations of total SCFAs were detected in the caeca. Enzyme supplementation raised the acetate concentration in the crop and total SCFAs in the caeca, but without significant changes in $\mathrm{pH}$ values. In our earlier experiments (Józefiak et al., 2004a), higher SCFA concentrations were also observed in caecal contents after $\beta$-glucanase supplementation of barley-based diets. In contrast, Lázaro et al. (2003), feeding broiler chickens with rye diets containing different amounts of enzyme preparations, did not detect a significant SCFA increase in the caeca. Choct et al. $(1996,1999)$ reported that SCFA concentrations were higher in the caeca but lower in ileal chyme following dietary enzyme supplementation. In contrast, in the present experiment, a tendency towards increased total and individual SCFAs in ileal chyme was observed.

The concentrations of SCFA and lactic acid as well as the $\mathrm{pH}$ values of the GIT chyme are closely related to the activity and density of the resident microflora (Engberg et al., 2002; Ricke, 2003). SCFAs and lactic acid can inhibit the growth of some intestinal bacteria, including E.coli and Salmonella, by dissipating the proton motive force across the bacterial cell membrane and by acidification of the cytoplasm (Russell, 1992). However, they do not inhibit Lactobacilli, which are generally recognized as beneficial in the chicken GIT. Thus, the presence of SCFA as well as factors that increase their concentration in the chicken GIT might have some health advantages for the bird. However, besides the dietary ingredient composition and feed additives (i.e. $\beta$-glucanase), many other factors should be taken into consideration when judging SCFAs and lactic acid effects. It is suggested that one of the most important factors is the age of the birds. Microflora succession in the GIT happens very fast and changes rapidly in the short broiler life, which makes it difficult to compare results regarding SCFAs concentrations from different studies using birds of different ages. Among all segments of the broiler GIT, the 
caeca are considered to be the main site of microbial fermentation (Józefiak et al., 2004a,b). In terms of SCFA concentrations, the results of the present experiment also support this thesis. It is suggested that the higher weight of the caeca is related to the presence of fermentable carbohydrates as well as insoluble dietary fibre in the diet (Duke et al., 1984). Compared with wheat or maize, barley contains higher amounts of (1-3)(1-4)- $\beta$-glucans as well as cellulose (Bach Knudsen, 1997). Thus, it could be expected that birds receiving diets with barley should have heavier caeca. Contrary to these expectations, however, comparison of the caeca weights from the experiment (including digesta) with those of broiler chicken fed wheat-based diets (Steenfeldt et al., 1998) failed to show any significant differences. In the present experiment, the relative liver weight was not affected by the enzyme supplementation. In contrast, Brenes et al. (1993) reported that $\beta$-glucanase inclusion in barley-based diets reduced broiler chicken liver weight by $8 \%$.

However, it seems that the reduction of ileal chyme viscosity is only one of the effects of the enzyme on broiler performance. $\beta$-glucanase supplementation also increased the acetate concentrations in the crop $(\mathrm{P} \leq 0.05)$ and total SCFAs in the caeca $(\mathrm{P} \leq 0.05)$. Changes in the fermentation end products in different GIT segments can suggest that bacterial populations are affected by enzyme supplementation. Thus, it is suggested that one of the $\beta$-glucanase effects in the broiler chicken diet could be modification of the resident microflora.

\section{CONCLUSIONS}

$\beta$-glucanase supplementation of barley-soyabean based diets lowers viscosity of the ileal chyme but also may change resident microflora activity affecting fermentation end products in the crop and caeca of broiler chickens. Therefore, it is suggested that, considering the role of $\beta$-glucanase in the broiler chicken, other segments of the gastrointestinal tract should also be examined besides the ileum.

\section{REFERENCES}

AOAC, 1990. Association of Official Analytical Chemists, Official Methods of Analysis. 15th Edition. Arlington, VA

Bach Knudsen K.E., 1997. Carbohydrate and lignin contents of plant materials used in animal feeding. Anim. Feed Sci. Tech. 67, 319-338

Bedford M.R., Apajalahti J., 2001. Microbial interactions in response to exogenous enzyme utilization. In: M.R. Bedford, G.G. Partrige (Editors). Enzymes in Farm Animal Nutrition. CABI Publishing, pp. 299-314

Bergh M.O., Razdan A., Åman P., 1999. Nutritional influence of broiler chicken diets based on covered normal, waxy and high amylose barleys with or without enzyme supplementation. Anim. Feed Sci. Tech. 78, 215-226 
Brenes A., Smith J., Guenter W., Marquardt R.R., 1993. Effect of enzyme supplementation on the performance and digestive tract size of broiler chickens fed wheat- and barley-based diets. Poultry Sci. 72, 1731-1739

Choct M., Hughes R.J., Bedford M.R., 1999. Effects of a xylanase on individual bird variation, starch digestion throughout the intestine, and ileal and caecal volatile fatty acid production in chickens fed wheat. Brit. Poultry Sci. 40, 419-422

Choct M., Hughes R.J., Wang J., Bedford M.R., Morgan A.J., Annison G., 1996. Increased small intestinal fermentation is partly responsible for the anti-nutritive activity of non-starch polysaccharides in chickens. Brit. Poultry Sci. 37, 609-621

Duke G.E., Ecclestone E., Kirkwood S., Louis C.F., Bedbury H.P., 1984. Cellulose digestion by domestic turkeys fed low or high fibre diets. J. Nutr. 114, 95-102

Elwinger K., Säterby B., 1987. The use of $\beta$-glucanase in practical broiler diets containing barley or oats. Swed. J. Agr. Res. 17, 133-140

Engberg R.M., Hedemann M.S., Jensen B.B., 2002. The influence of grinding and pelleting of feed on the microbial composition and activity in the digestive tract of broiler chickens. Brit. Poultry Sci. 43, 569-579

Englyst H.H., Cummings J.H., 1984. Simplified method for the measurement of total non-starch polysaccharides by gas-liquid chromatography of constituent sugars as alditiol acetates. Analyst 109, 937-942

Jamroz D., Jakobsen, K., Bach Knudsen K.E., Wiliczkiewicz A., Orda J., 2002. Digestibility and energy value of the non-starch polysaccharides in young chickens, ducks and geese, fed diets containing high amounts of barley. Comp. Biochem. Physiol. 131, 657-668

Jamroz D., Orda J., Wiliczkiewicz A., Skorupińska J., 2001. Efficacy of carbohydrases derived from Trichoderma longibrachiatum in wheat- and barley-based diets on performance and fermentation of carbohydrates in the intestine of broilers. J. Appl. Anim. Res. 19, 61-72

Jensen M.T., Cox R.P., Jensen B.B., 1995. Microbial production of skatolein the hindgut of pigs given different diets and its relation to skatole deposition in backfat. J. Anim. Sci. 61, 293-304

Józefiak D., Rutkowski A., Frątczak M., Boros D., 2004a. The effect of dietary fibre fractions from different cereals and microbial enzymes supplementation on performance ileal viscosity and short-chain fatty acids concentration in caeca of broiler chickens. Anim. Feed Sci. Tech. 13, 487-496

Józefiak D., Rutkowski A., Martin S.A., 2004b. Carbohydrate fermentation in the avian caeca. A review. Anim. Feed Sci. Tech. 113, 1-15

Langhout D.J., Schutte J.B., Van Leeuwen P., Wiebenga J., Tamminga S., 1999. Effect of high- and low-methylated citrus pectin on the activity of the ileal microflora and morphology of the small intestinal wall of broiler chicks. Brit. Poultry Sci. 40, 340-347

Lázaro R., Garcia M., Medel P., Mateos G.G., 2003. Influence of enzymes on performance and digestive parameters of broilers fed rye-based diets. Poultry Sci. 82, 132-140

Ricke S.C., 2003. Perspectives on the use of organic acids and short chain fatty acids as antimicrobials. Poultry Sci. 82, 632-699

Russell J.B., 1992. Another explanation for the toxicity of fermentation acids at low pH: anion accumulation versus uncoupling. J. Appl. Bacteriol. 73, 363-370

SAS, 1988. SAS ${ }^{\circledR}$ User's Guide: Statistics SAS Institute Inc., Cary, NC

Silva S.S.P., Smithard R.R., 2002. Effect of enzyme supplementation of a rye-based diet on xylanase activity in the small intestine of broilers, on intestinal crypt proliferation and nutrient digestibility and growth performance of the birds. Brit. Poultry Sci. 43, 274-282

Smith C.H.M., Annison G., 1996. Non-starch plant polysaccharides in broiler nutrition-towards a physiologically valid approach to their determination. World Poultry Sci. J. 52, 203-221 
Steenfeldt S., Müllertz A., Fris Jensen J., 1998. Enzyme supplementation of wheat-based diets for broilers. Effect on growth performance and intestinal viscosity. Anim. Feed Sci. Tech. 75, 27-43

Svihus B., Gullord M., 2002. Effect of chemical content and physical characteristics on nutritional value of wheat, barley and oats for poultry. Anim. Feed Sci. Tech. 102, 71-92

\section{STRESZCZENIE}

\section{Wpływ dużego udziału jęczmienia $w$ diecie i dodatku $\beta$-glukanazy na przebieg fermentacji w przewodzie pokarmowym kurcząt rzeźnych}

Przeprowadzono 5 tygodniowe doświadczenie na 192-jednodniowych-kogutkach Cobb 500, przydzielonych losowo do dwóch grupy doświadczalnych, w każdej po 12 klatek (powtórzeń), po 8 kurcząt. Celem doświadczenia było określenia wpływu dodatku egzogennej $\beta$-glukanazy do diety jęczmienno-sojowej na wyniki odchowu, lepkość treści jelit, $\mathrm{pH}$ oraz koncentrację krótkołańcuchowych kwasów tłuszczowych (KŁKT) i kwasu mlekowego w wolu, mielcu, jelicie cienkim i jelitach ślepych kurcząt rzeźnych. Dodatek $\beta$-glukanazy istotnie poprawił współczynnik wykorzystania paszy $(1,9$ vs 1,85$)$ tylko w okresie grower (15-35 dni), nie wpłyną natomiast na przyrost masy ciała oraz masę wątroby i jelit ślepych. Zastosowanie $\beta$-glukanazy obniżyło lepkość treści jelita biodrowego $(\mathrm{P} \leq 0,05)$ oraz spowodowało zmiany w koncentracji KŁKT w treści wola i jelit ślepych. Koncentracja kwasu mlekowego była najwyższa w treści jelita biodrowego, następnie wola, mielca i jelit ślepych. Całkowita ilość KŁKT była największa w treści jelit ślepych, następnie jelita biodrowego, wola i mielca. Po dodaniu $\beta$-glukanazy do diety w treści wola wzrosła ilość kwasu octowego, natomiast w jelitach ślepych koncentracja KŁKT oraz kwasu propionowego. $\mathrm{W}$ żadnym $\mathrm{z}$ badanych odcinków przewodu pokarmowego dodatek $\beta$-glukanazy nie wpłynął na zmianę pH treści. 